\title{
STATE ADMINISTRATIVE SUPERVISION OF LOCAL GOVERNMENT DEBT: THE NORTH CAROLINA MODEL
}

The need for modernization and expansion of a broad range of public services has made municipal borrowing an increasingly important, ever expanding process. ${ }^{1}$ Yet because of a concern for the individual taxpayer and a sense of fiscal responsibility refined through past experiences with debt issuance, ${ }^{2}$ virtually all states today place

1. Borrowing by state and local governments through the sale of municipal bonds attained a new peak of over \$24 billion in 1971. 47 MuN. FiN. OfFicers Ass'N NewsLetTer 5 (1972). This figure exceeds by more than $\$ 6$ billion the previous record total of $\$ 17.5$ billion which was reported for 1970 in The Weekly Bond Buyer (January, 1970 Municipal Bond Sales Section, March 22, 1971) at 16.

THE FOLLOWING HEREINAFTER CITATIONS WILL BE USED IN THIS NOTE:

State and local. Publ.ic Fachi.tTy Needs and Financing, Study Prepared for the Subcomittee on Economic Progress of the Jolnt Economic Committee, 89th Cong., 2d Sess. (1966) [hereinafter cited as StunY];

Advisory Comm'n on Intergovernmental Relations, State Technical Assistance to LoCal. Debt Managenent (1965) [hereinafter cited as Advisory Comm'N, State TeChNiCal. Assistance];

Advisory Comm'N on Intergovernmental Relations, State Constitutional and Statutory Restrictions on Local Government Debt (1961) [hereinafter cited as ADVISORY COMM'N, STATE RESTRICTIONS];

R. BYRD, CoLnty Finance (N.C. Institute of Gov't Series 1967) [hereinafter cited as BYRD];

A. Hill.house, Municipal. Bonds: A Century of Experifnce (1936) [hereinafter eited as HII.1.HOUSE];

H. Secrist, An Economic Analysis of the Constitutional Restrictions Upon PubI.IC INDEBTEDNESS IN THE UNITED STATES (1914) [hereinafter cited as SECRIST];

P. Studensky, Pubi.sc Borrowing (1930) [hereinafter cited as Studensky];

Bowmar, The Anachronism Called Debt Limitation, 52 lowA L. REv. 863 (1967) [hereinafter cited as Bowmar];

Fesler, North Carolina's Local Government Commission, 30 NAT'L MuN. REv. 327 (1941) [hereinafter cited as Fesler];

McMahon, The North Carolina Local Government Commission, in 1960 CounTY YEARBOOK OF THE N.C. Ass'N OF COUNTY CoMm'RS [hereinafter cited as McMahon]:

Stason, State Administrative Supervision of Municipal Indebtedness, $30 \mathrm{MICH}$. L. REv. 833 (1932) [hereinafter cited as Stason];

Interview with Edwin T. Barnes, Deputy Secretary, North Carolina Local Government Commission, in Raleigh, N.C., Mareh 1, 1972 [hereinafter cited as Barnes Interview].

2. States are concerned with insuring the fiscal responsibility of local governments because of the risk of citizens losing confidence in a financially insecure local government, the threat to individuals of burdensome taxation due to overborrowing by municipalities, and the possibility of harm to the municipal creditor. See Kiernan, Kubale \& Bugge, Wisconsin Municipal Indebtedness: Conclusions and Recommendations, 1964 WIS. L. REV. 604, 605. Uncontrolled- 
either constitutional or statutory limits upon the power of municipalities to incur debt. ${ }^{3}$ In the inevitable collision between municipalities' kinetic demands for monies and these often-termed "inflexible" or "anachronistic" state limitations, ${ }^{4}$ methods for circumventing the restrictions have been devised which in many cases have resulted in high levels of poorly planned debt. ${ }^{5}$ Despite suggestions that all quantitative debt restrictions be abolished, ${ }^{6}$ some state control over the level of municipal debt issuance seems inevitable; the fundamental question is how varying local needs for borrowed funds can be reconciled more effectively with state interests in maintaining a reasonable ceiling on debt. ${ }^{7}$

During the Depression, when constitutional and statutory limitations failed to halt a surge of borrowing and subsequent defaults by local units, the state of North Carolina enacted a statutory scheme which provided for centralized control of all local debt issuance by a state administrative body, the Local Government Commission. ${ }^{8}$ For forty years the Commission has assisted local units in debt planning and management, helping them to avoid unnecessary debt and building a system through which local units have been able to issue debt

debt issuance by a local government may severely limit its ability to borrow in the future and thus prospectively impair its budgetary fexibility; at the same time a single unit's excesses may increase the cost of borrowing for many other units within a state by diminishing the confidence of investors. ADvisory COMm'N, State Restrictions 37-38.

3. The most widely used state controls upon municipal debt seek to limit the quantity of debt which a local government may incur. The constitutional or statutory provision which limits the level of debt to a stated percentage of assessed property values within a local unit is the primary type employed. F. StaRner, General Obligation Bond Financing by LoCAl GOVERNMENTS: A SURVEY OF STATE CọnTROLS 8 (1961). See notes 23, 33 infra and accompanying text. Other quantitative controls include ceilings on tax rates which limit the amount of tax that can be levied for debt service requirements, and rcquirements that proposed bond issues be approved by referendum. Advisory COMM'N, STATE RESTRICTIONS 30-33. In addition, some states attempt to control the compositon and quality of municipal debt. See notes 35-38 infra and accompanying text.

4. See, e.g., Bowmar 891-94; Magnusson, Lease-Financing By Municipal Corporations as a Way Around Debt Limitations, 25 Geo. WASH. L. Rev. 377, 394-95 (1957); Comment, Municipal Debt Limitations in Pennsylvania, 15 VILL. L. Rev. 612, 629 (1970).

5. See notes 27-33 infra and accompanying text.

6. See Magnusson, supra note 4, at 395; Note, Constitutional Restrictions Upon Municipal Indebtedness, 1966 UtAн L. Rev. 462, 487. See generaily Aronson, A Comment on Optimality in Local Debt Limitations, 24 NAT'L TAX J. 107 (1971); Hand \& Mitchell, Optimality in Local Debt Limitation: Comment, 24 NaT'L TAX J. 101 (1971).

7. For suggestions concerning the attainment of this balance see ADVISORY COMM'N, STATE RESTRICTIONS 65-85.

8. The Local Government Act, ch. $60, \S \S 1-78,[1931]$ N.C. Pub. Laws $60-84$. 
at lower costs. This Note will describe the North Carolina statute's unique position in the historical and definitional background of traditional debt restrictions, explain the statutory scheme and its implementation, and critically examine the continuing viability of the provisions and their significance for state and local governments generally.

\section{Historical Origins of Debt Restrictions}

The imposition of restraints upon municipal borrowing can be traced to the experiences of the states during three periods of national economic expansion. ${ }^{9}$ In the first half of the nineteenth century the states themselves borrowed extensively in order to make public improvements to promote the nation's growth. ${ }^{10}$ However, following the Panic of 1837 when most of the debts came due, many states found revenues insufficient to cover their obligations. ${ }^{11}$ As part of a general movement to curb legislative powers and as a specific reaction to these borrowing excesses, voters in many states approved constitutional limitations on the state's power to incur debt. ${ }^{22}$ During the period between the end of the Civil War and 1900, constitutional prohibitions against state borrowing to fund public improvements were interpreted as restricting only the state governments. ${ }^{13}$ As a result, municipalities were able to continue unlimited borrowing to expand public services, ${ }^{14}$ and more significantly, to give credit backing to private industries (particularly the railroads) in order to encourage investment. ${ }^{15}$ When many municipalities defaulted on their

9. An excellent summary of this historical development is K. BEASLEY, State SUPERviSion of Municipal Debt in Kansas: A Case Study 4-14 (1961). See also P. Studensk1 \& H. Krooss, Financial History of the United States 128-36, 192-200, 344-52 (1952). For further historical treatment of the evolution of municipal debt restrictions see HILLHOUSE; SECRIST 54-73; STUDENSKY.

10. For discussion of the historical origins of state borrowing and the imposition of restraints thereon, see generally B. Ratchford, AMERICAN STate DebTs (1941); W. SCOTT, The Repudiation of State Debts (1893); Secrist 13-31; StUdensky 7-9.

11. See B. RATCHFORD, supra note 10 , at $86-87,96-100$.

12. Id. at 121-22. See SECRIST 32-44 for description of the types of restrictions which were imposed.

13. SECRIST 63-65.

14. See HiLlhouse 34.

15. American businessmen financed the westward expansion of the railroads through sales of securities to an eager market, a large segment of which was foreign. As investors demanded guarantees for these loans, many local governments backed the debts with their taxing power, viewing the increased values which were expected to result from the development of commerce 
bonds following economic declincs in 1873 and in the 1890 's ${ }^{10}$ states responded to the demands of overburdened taxpayers and emptyhanded bondholders by setting constitutional and statutory standards which typically prohibited municipal investment of public money in private concerns and established debt limits for local units, expressed as percentages of property values. ${ }^{17}$ But as municipal defaults declined after 1900, local units began to make steady increases in debt which accelerated after World War I-restrictions on borrowing were bypassed as debt limits were ignored, overlapping units created, old services expanded, and new services added.$^{18}$ At the outset of the Depression, municipal credit was again overextended and defaults began to occur. ${ }^{19}$ Nevertheless, a number of deficient units continued to borrow, prompting a number of states not only to tighten constitutional and statutory debt restrictions, but also to institute centralized supervision of certain aspects of municipal debt incurrence. ${ }^{20}$

Each of these three periods encompassed a common cycle. ${ }^{21}$ Rapid ecoriomic growth spurred local borrowing intended to lend momentum to developing business and industry. When the economy slowed and the flow of money diminished, state units found their credit overextended and their ability to repay outstanding obligations overreached. In each instance the states reacted by imposing borrowing restraints designed to prevent recurrence of the cycle, thus forming the bases for the present constitutional, statutory, and administrative measures for control and management of local debt.

\section{Types of Debt Restrictions}

State constitutional ceilings on municipal borrowing are the most

both as a justification for their debt incurrence and as a means for payment of the debt. In most instances these schemes were approved by the courts. SECRiST 54-55. See C. CHATTERS, Municipal. Debt Defauits: Their Prevention and Adjustment 10-13 (1933); Hillhouse 143-99.

16. See Hit.hHOUSE 39-42.

17. See Secrist 59-63, 70-71; STUdensky 12.

18. HILLHOUSE 3-4. 30.

19. For discussion of the scope of municipal defaults during the Depression see $i d$. at 12 -

20. An analysis of these attempts at control of debt through administrative supervision is found in Stason 842-58.

21. See Hil.thouse 238-39; Studensky 30-31; Note, supra note 6, at 463. 
widespread and the most restrictive type of debt limitation..$^{22}$ Designed to prevent local financial irresponsibility with its concomitant overtaxation and default on municipal obligations, these provisions remove from both citizens and legislatures the ability to incur debt beyond a stated maximum. The typical constitutional limit restricts the total amount of debt that may be outstanding at any time, whether approved by the local voters or not, to a fixed percentage of the assessed value of the real property within a municipality. ${ }^{23}$ Since such debt ceilings can be changed solely through the extended process of amendment to the state constitution, they consequently preclude exceptions which might be made in especially meritorious cases. In addition, their scope is indiscriminate, applying alike to areas with greater and lesser needs to incur debt. ${ }^{24}$ Moreover, such constitutional restrictions attempt to control merely the quantity rather than the quality of indebtedness, and within the prescribed limits borrowing and spending are unrestricted. ${ }^{25}$

Constitutional debt limits have often failed to perform even the limited role of placing a ceiling on debt. Faced with demands for funds, local units have circumvented these rigid provisions through methods which have not only nullified the quantitative restrictions but have often effectuated the very evils the provisions were designed to prevent. ${ }^{26}$ For the performance of such isolated functions as sanitation and education, municipalities have created special districts or authorities which are considered independent governmental units, in some instances capable of borrowing up to the constitutional maximum. ${ }^{27}$ Such districts retire debt through general property taxes, special assessments, or increased user charges. As the taxpayer becomes obligated to one or more special districts in addition to his home municipality, his actual financial burden may easily exceed that

22. See Kiernan, Kubale \& Bugge, supra note 2, at 605 n.947 (noting proliferation of constitutional restrictions); Comment, supra note 4 , at 628 (citing inherent inflexibility of this type of restriction).

23. Bowmar 866 . Other states use a limit based on the same debt/property ratio with a provision for a higher percentage limit where debt issuance is approved by local voters, or limit debt to current annual revenues, with an allowance for additional voter-approved indebtedness up to a designated percentage of assessed valuation. Id. at 866-67.

24. Stason 838-39.

25. Id. at 838 .

26. See Note, supra note 6 , at 487 .

27. Bowmar 868-69. 
envisioned by the constitutional limit. ${ }^{28}$ Moreover, in spite of constitutional restrictions, units which have reached the debt maximum may finance self-supporting improvements through revenue bonds. These bonds are redeemed solely through funds derived from operation of facilities constructed with the proceeds from the bonds..$^{20}$ Since revenue bonds are not guaranteed by the full taxing power of the local government, they are usually omitted from computations of debt for purposes of quantitative debt restrictions. ${ }^{30}$ Taxpayers still repay the debt through user charges or special assessments, and since such bonds are not supported by the taxing power of the community, they entail higher interest costs than if the municipality had issued general obligation bonds. ${ }^{31}$ Circumvention has also been achieved through debt incurred in long term sales or lease agreements, where periodic payments for capital improvements made from current annual revenues are considered a current expense. ${ }^{32}$ However labeled, this practice constitutes borrowing, and the taxpayer still provides the funds for the rental or installment payments. ${ }^{33}$

Perhaps because of the negative character of constitutional debt restrictions, a number of states have chosen to rely heavily upon statutory schemes for the control of local debt. Such provisions may

28. Id. at 870 . For more detailed discussion of the phenomena of special districts and authorities, see Advisory Comm'n on Intergovernmental Relations, The Problem of Special. Districts in American Government (A-22 1964); J. Bollens, Special District Governments IN THE United States (1961); Morris, Evading Debt Limitations with Public Building Authorities: The Costly Subversion of State Constitutions, 68 Y ALE L.J. 234 (1958); Williams \& Nehemkis, Municipal Improvements as Affected by Constitutional Debt Limitations. 37 COLUM. L. Rev. 177, 201-08 (1937).

29. Operating revenues may include tolls, charges, rents, or assessments paid by persons using or otherwise benefiting from the improvement. INVESTMENT BANKERS Ass'N OF AMERICA, FUNDAMENTALS OF MUNICIPAL BONDS 3 (4th ed. 1965). In contrast, general obligation bonds are backed by the taxing power of the issuing municipality to insure their payment. Id. See aiso A. Rabinowitz, Municipal Bond Finance and Administration 33 (1969).

30. See generally Advisory Comm'N, State Restrictions 53-57; J. Maxwell, FinanCing State and Local Governments 199-205 (1965).

31. Advisory Comm'n, State Technical Assistance 6-7; Advisory Conm'n, State RESTRICTIONS 55-56; MAXWELL, supra note 30, at 204-05.

32. Local governments thus encourage a private party to construct a facility and then pay the party rent for its use. In some states, rent to fall due after the current rental period does not constitute present debt; therefore, the indebtedness of the municipality is increased not by the full cost of the improvement, but only by the annual rent, even though the unit takes title when rents have equalied the cost of the improvement. Magnusson, supra note 4, at 377. See also Rogers, Municipal Debt Restrictions and Lease-Purchase Financing, 49 A.B.A.J. 49 (1963).

33. Magnusson, supra note 4 , at $390-94$. 
merely establish the same quantitative debt ceilings found in the constitutions of other states and thus may represent only a slight improvement over those restrictions. ${ }^{34}$ On the other hand, statutory plans may attempt to determine municipal debt qualitatively as well as to limit it quantitatively. Statutes which control the quality of local debt tend to limit its quantity at the same time and afford a better approach toward balancing the state's desire for debt limitation and local needs for funds than do arbitrary debt ceilings alone. Moreover, statutes which emphasize responsible debt management serve the municipality through savings realized by efficient debt issuance; at the same time, the state interest in limiting debt is effectuated when community demands for increased borrowing slacken due to more careful debt planning by local officials and due to the savings realized through well-managed debt. Qualitative statutory guidelines are designed to insure that the character of local debt will fall within certain bounds deemed desirable by the legislature. For example, they may limit net debt; set bounds for bond maturity schedules, sales prices, and the manner of sale; and restrict the use of borrowed funds. ${ }^{35}$

As part of a state's statutory law, such plans are more susceptible to modification and exception than are constitutional debt limits. Yet, on the whole, they are still unresponsive to change..$^{36}$ Furthermore, no one statutory scheme seems capable of providing effective guidance to all of the varying municipal units within a state. Drafted too narrowly, such statutes may restrict legitimate activity of wellmanaged local units; drawn too broadly, they may permit mismanagement. ${ }^{37}$ However well-written the statute, the potential for misunderstanding by local officials is always present. ${ }^{38}$ Genuine disputes

34. As statutes, they are easier to amend and subject to legislative exception, in contrast to constitutional restrictions which require the extended process of amendment to the state constitution for change or exception.

35. See Stason 840-42. Minnesota's Municipal Bond Code exemplifies the statutory scheme for qualitative debt control. MINN. STAT. ANN. $\$ 475.50-.753$ (1963), as amended, (Supp. 1971). For a general explanation of the functioning of the Minnesota statute, see Howard, Current Municipal Bond Procedures in Minnesota, 40 MiNN. L. Rev. 145 (1956); Howard, An Outline of Municipal Bond Procedure in Minnesota. 20 MiNN. L. Rev. 583 (1936). North Carolina's Local Government Act is essentially the same type of plan, with the exception of the important additional provision for interpretation and review by a state administrative body-the Local Government Commission-of adherence to the statute. N.C. GeN. STAT. $\$ 159-1$ to -68 , as amended, (Supp. 1971).

36. Where statutes merely set quantitative debt limits, they can be subject to the same circumvention as constitutional restrictions. See notes 26-33 supra and accompanying text.

37. See Stason 842 .

38. Id. 
can be settled only by litigation; moreover, the burden is usually on the local citizen to bring suit when he is threatened with injury. ${ }^{30}$

After encountering the shortcomings of constitutional and statutory debt controls, certain states have realized that maintenance of local fiscal responsibility and conservation of the taxpayer's dollar ${ }^{40}$ not only requires measures designed to prevent misuse of local funds but also calls for state assistance which will insure a high quality of debt management by municipalities. Thus states have created administrative agencies which exert varying levels of control over local debt. ${ }^{41}$ Because centralized control over local debt has been opposed by many local governments and legislatures on the grounds that such supervision restricts the right of municipal officials to operate within the framework of the law, destroys local initiative, and establishes a politically-oriented bureaucracy, ${ }^{42}$ a number of states have limited these agencies to providing debt management assistance on a strictly voluntary basis. A well-planned example is the Vermont Municipal Bond Bank, a state agency which for a minimal charge will buy bonds from local units and resell them under its own name. ${ }^{43}$ So long as it sells bonds to the Bond Bank, a Vermont municipality is not bound by the state's constitutional debt limit; moreover, it receives the benefit of lower interest costs through the agency's handling of the sale. Other states provide for a mandatory review of the legality of proposed debt issuance in order to correct local abuses in the borrowing process, to insure compliance with constitutional and statutory provisions which authorize debt incurrence and require debt retirement, and to assure taxpayers and investors of the authenticity and legality of the bonds or notes to be issued. ${ }^{44}$ For example, Louisiana requires a local unit to submit any proposed bond issue to the State Bond and Tax Board prior to the mandatory referendum approval by the unit's

39. Id.

40. See note 2 supra.

41. See generally Advisory Comm'N, State TECHNiCAl Assistance 21-22; Study 25256. For a survey of early state administrative controls, see Stason 842-54.

42. See Craigie, "Centralize!"-A Call for Streamlined Bidding, The Daily Bond Buyer (MFOA Special Conference Issue No. 1, May 28, 1962) at 39, 40; Stason 854-55.

43. See Vt. Stat. AnN. tit. 24, \$4551-4710 (Supp. 1970); Heeseler, The Case for Municlpal Bond Banks, The Bond Buyer (Daily \& Weekly) (MFOA Special Conference Issue No. 2, June 21,1971$)$ at 27,45 . Virginia provides optional financial services to municipalities which include a successful system for marketing their bonds. See Advisory COMM'N, STATE TECHNICAL Assistance 55-59; STUDY 255-56; Craigie, supra note 42, at 39. Michigan and Tennessee also offer voluntary assistance. STUDY $252-53$ \& n. $16,255$.

44. Advisory Comm'n, State Technical Assistance 52-54. 
voters. ${ }^{45}$ Proposed bond issues are scrutinized to insure their conformity to the law and, in the case of revenue bonds, their economic feasibility ${ }^{46} \mathrm{~A}$ state may also combine voluntary and mandatory administrative controls over local debt issuance, as demonstrated by the Division of Local Finance and the Local Finance Board of New Jersey. Although local units customarily issue bonds according to procedures set forth in the New Jersey Bond Law ${ }^{47}$ without any requirement for approval by the Division of Local Finance, the Division exerts important controls on debt issuance. ${ }^{48}$ On the other hand, upon request, the Division will lend any local unit advice and assistance in financial planning, including aid in the sale and issuance of bonds. ${ }^{49}$

At the opposite end of the spectrum from purely voluntary agency aid are state plans which provide for mandatory review not only of the legal aspects of a proposed debt issue, but of its economic feasibility as well. ${ }^{50}$ North Carolina's Local Government Act ${ }^{51}$ falls within this classification and is the most comprehensive of all of the state provisions for centralized supervision of municipal debt issuance.

\section{Origin of the North Carolina Statute ${ }^{52}$}

\section{Because of a seven-fold increase in debt following World War I,}

45. See LA. Rev. Stat. ANN. $\$$ 47:1801 to :1808 (1950).

46. Letter from H. L. Oncal, Jr., Secretary, The Louisiana State Bond and Tax Board, to the Duke Law Journal, November 15, 1971.

47. N.J. Stat. ANN. $\$ 40 A: 2-1$ to -64 (Supp. 1971).

48. All local budgets must be submitted to the Division for approval, and one of the main points reviewed is the budget provision for debt service obligations in the upcoming year. Should a New Jersey unit fail to repay its indebtedness on schedule, it becomes subject to receivership and operation by the Municipal Finance Commission. The Local Finance Board has authority to waive statutory debt limitations in appropriate cases, adding flexibility to the state's quantitative debt restrictions. Letter from R. F. Keevey, Chief, The Office of Management \& Administration, New Jersey Division of Local Government Services to the Duke Law Journal, December 14, 1971.

49. Id. See generally New Jersey Administrative Procedures, tit. 5 (Department of Community Affairs), subtit. D (Division of Local Finance); G. SKILlMAN, A History of THE Division of LoCAL GOVERNMENT 1917-1967 (1967) (published by the Division of Local Government). For accounts of the early work of the New Jersey agency see Hendrickson \& Burger, New Jersey Reaps Fruits of Good Municipal Finance Laws, 32 NaT'L MUN. Rev. 419 (1943); Hoffman, A State Department of Local Government, 28 NAT'L MUN. Rev. 348 (1939).

50. Louisiana, Miehigan, and North Carolina are the only states with agencies exercising "coercive" scrutiny of all local bond issues. Advisory CoMm'N, STATE TECHNICAL Assistance 22.

51. N.C. GeN. StAT. \$ 159-1 to -68 (1964), as amended, (Supp. 1971).

52. A thorough treatment of the background of the statute is contained in McMahon 93100. See also Brookings Institution, State Centralization in North Carolina 80-106 
North Carolina's local governments by 1931 found their financial status bleak. In the period preceding 1931, the state's municipalities had financed roads, schools, and other capital improvements through the issuance of bonds. ${ }^{53}$ Most issues had been readily sold to eager buyers in the speculative market of the 1920's, and the lack of any effective control over debt incurrence had provided a further incentive to borrowing..$^{54}$ Defaults had occurred with the bulk of the local debt remaining to be paid during the next decade. ${ }^{55}$ Sinking funds, which were intended to be built up incrementally to pay term bonds ${ }^{56}$ when they came due, had in many cases been diverted and spent for other purposes or had never been established ${ }^{57}$ In some instances where sinking funds had been initiated, the collapse of banks had tied up the cash deposited. ${ }^{58}$ Many serial bonds had been improperly scheduled, resulting in unreasonable payment burdens for certain years..$^{50}$ The Depression aggravated all of these problems. Tax revenues followed the decline of property values, while local demands for new and increased public services grew. Yet local citizens opposed any increase in taxes and even protested the enforcement of existing levies. ${ }^{.0}$ Neither the County Government Advisory Commission, which had been formed to advise and assist local governmental officials, ${ }^{01}$ nor the State Sinking Fund Commission, which had been given the task of approving all bonds and notes proposed to be issued, ${ }^{02}$ seemed able

(P. Betters ed., Institute for Gov't Research, Studies in Administration No. 26, 1932); Brookings INSTITUTION, RePORT ON A SURVEY OF THE ORGaNization ANd AdMINISTRATION of County Government in North Carolina 79-87 (1930); Fesler 327-29.

53. McMahon 98.

54. Id.

55. Fesler 327.

56. Term bond refers to the type of debt issuance in which all or the major part of an issue is scheduled to be repaid within a single year. On the other hand, a serial bond is part of an issue of bonds which are due in a series of consecutive years. (For instance, where a unit sells bonds to fund a facility, marking some for payment in 1984, some in 1986, some in 1988, etc.). See RABINowitz, supra note 29 , at 34 . A unit which issues term bonds and fails to make annual provisions for repayment by depositing revenues in a sinking fund will find itself impossibly over-burdened financially in the year in which the bonds fall due.

57. Brookings Institution, State Centralization, supra note 52, at 98-99; BROOKINGS INSTITUTION, RePORT, supra note 52, at 87; Fesler 327.

58. Fesler 327.

59. Id. at $327-28$.

60. Id. at 328 .

61. See Brookings institution, State Centralization, supra note 52, at 89-94; McMahon, 96-98.

62. See Brookings INSTITUTION, Report, supra note 52, at 85; McMahon 98. 
to cope with the fiscal problems of the state's municipalities. Thus, in 1931 the North Carolina General Assembly passed the Local Government Act, ${ }^{63}$ creating a far-reaching statutory scheme to guide local debt management and delegating to the Local Government Commission broad powers to effectuate the policies and dictates of the Act. The provisions of this Act remain substantially unchanged today. ${ }^{64}$

The Local Government Act and the Role of the Local Government Commission $^{65}$

Composed of four ex officio memhers and five other members appointed by the governor. ${ }^{68}$ the North Carolina Local Government Commission functions as a separate and distinct division of the Department of the State Treasury. ${ }^{67}$ The ex officio members constitute the Commission's executive committee which is empowered to act for the entire Commission, ${ }^{68}$ subject to review by the Commission upon the application of any aggrieved party who files for review within five days after the challenged action ${ }^{69}$ The State Treasurer, acting in his capacity as Director of Local Government, selects the Secretary and Deputy Secretary of the Commission who are retained as permanent employees. ${ }^{70}$ In practice, the Secretary, the Deputy Secretary, and their staff make the basic decisions of the Commission, and the fulltime employees perform substantially all of its work. The Secretary's

63. Ch. 60, $\S 1-78,[1931]$ N.C. Pub. Laws $60-84$.

64. In 1971 a revision of the Act which will become effective July 1, 1973, was approved by the North Carolina General Assembly. The Local Government Finance Act, ch. 780, $\$ §$ ___ [1971] N.C. Session Laws ___ compiled in N.C. GEN. STAT. $\$ 159-1$ to -182 (Supp. 1971) (eff. July 1, 1973). This new version clarifies the language of the statute and consolidatcs a number of provisions relevant to local government finance which were previously scattered throughout the North Carolina statutes; however, the Act's basic provisions remain unchanged. Several minor changes effected by the new statute will be noted below.

65. See generally R. Rankin, The Government and administration of North CaroI.INA 383-89 (1955); McMahon 115-45.

66. N.C. GEN. STAT. \& 159-3 (Supp. 1971). The State Auditor, State Treasurer, Secretary of State, and Commissioner of Revenue are members ex officio. One of the other five appointed members must have had experience as the chief executive officer or member of the governing board of a city or town, and one must have had experience as a member of the governing body of a county at the time of appointment. Id.

67. Id.

68. Id. $\S 159-4$ to -5 (1964).

69. Id. at $\S 159-6$. Executive Committee approval of notes maturing not more than six months from their execution is excepted from the review provision.

70. Id. § 159-3 (Supp. 1971). 
decisions are almost always accepted by the executive committee, and the procedure for appeal to the full commission from the executive committee is never utilized. ${ }^{11}$

Whenever a local unit in North Carolina incurs debt through the sale of bonds or notes, the Local Government Commission is responsible for supervising all aspects of the debt issuance process. In the initial pre-election or pre-sale phase, the governing body of any local unit in the state that proposes to issue bonds or notes must submit a plan for the proposed issue to the Commission for approval. ${ }^{12}$ To assist in determining whether the debt should be allowed to be incurred, the Act provides the Commission with thirteen broad bases for decision, ranging from the public need for the improvement which is to be made from the bond sale proceeds to more concrete criteria concerning the financial status of the unit. ${ }^{73}$ In addition, the Commission may scrutinize "[a]ny other matters which [it] may believe to have a bearing on the question presented."74 This unique grant to the Commission of power to screen every issuance of bonds or notes in the state prior to submission of the question to voters of the local unit or prior to sale where a referendum is not required ${ }^{75}$ is fundamen-

71. The Executive Committee provides its important control function through raising, discussing, and resolving broad policy issues which may confront the Commission, rather than participating in its day to day technical decisions. Barnes Interview.

72. N.C. GEN. STAT. § 159-7 (1964). Where the proposed issue is subject to voter approval, see note 75 infra, the unit's governing board must provide notice of its intention to apply to the Commission ten days before filing an application. N.C. GEN. STAT. § 159-7.1 (1964). The statutory command clearly encompasses all the state's municipalities which have the power to create debt: "the word unit will be used to refer to a eounty, city, town, incorporated village, township, school district, school taxing district or other district or political subdivision of government of the State ...."Id. § 159-2. See id. $\$ 159-42$ (Supp. 1971).

73. Id. § $159-8$ (1964).

74. Id. If the Commission finds that the issuance of the proposed obligations is "necessary or expedient" and financially feasible as defined by six enumerated criteria, it must approve the issuance. Id. § 159-9.

75. The North Carolina Constitution provides that "[n]o county, city or town, or other municipal corporation shall contract any debt, pledge its faith, or lend its credit except for the necessary expense thereof, unless approved by a majority of the qualified voters who shall vote thereon in any election held for that purpose." N.C. ConsT. art. V, $\S 4(2)$. Thus, all debt issued for "nonnecessary" expense functions must be approved by a unit's voters. BYRD 36 . What constitutes "necessary" expense is a question of law to be determined finally by the North Carolina Supreme Court. Id. at 22. Bridges, certain publie buildings, and local needs such as law enforcement, municipal water systems, electrical plants, and fire protection have been termed necessary; important functions classed as "nonnecessary" expenses include airports, hospitals, libraries, and recreation. Id. at 24-25, 30-32. See generally id. at 22-45; Coates \& Mitchell, "Necessary Expenses" Within the Meaning of Article VII, Section 7, of the North Carolina Constitution, 18 N.C.L. REv. 93 (1940); Note, Airport Not A "Necessary Expense" 
tal to the Commission's role as a force for improving the quality of local debt management.

The actual decision by the Commision to approve or disapprove the proposed issue is usually made prior to formal application by the local unit. Ordinarily, officials of a municipality interested in issuing debt contact an officer of the Commission, submit data about their local unit and the proposed issue, and then meet in informal conference with the Secretary or Deputy Secretary to discuss the feasibility of the issue. ${ }^{76}$ In assessing a proposed issue according to the standards provided by the statute, ${ }^{77}$ the Commission usually bases its decision primarily on the financial factors which affect the marketability of the unit's bonds ${ }^{78}$ and may offer suggestions to the local government for amending its proposal to gain Commission approval. If the Commission and the unit are unable to agree about the proposed issue, the unit usually discontinues its plans for issuing debt. Should the unit nevertheless provide notice and file a formal application for this procedure which is then tentatively disapproved by the executive committee, the officer or governing board of the unit filing the application may request a public hearing ${ }^{79}$ and reconsideration by the committee, after which the committee must enter an order stating the reasons for

Within Meaning of Article VII, Section 6, of North Carolina Constitution, 46 N.C.L. ReV. 188 (1967).

Furthermore, voter approval is required for a unit to contract debt if the amount of debt already contracted in a fiscal year exceeds two-thirds of the net debt reduction for the preceding year or would exceed that sum if the proposed debt were issucd. See N.C. Const. art V, $\S 4(1)$. For discussion of the "two-thirds limitation" see BYRD 250-65. Debt issued for four purposes is specifically excepted from the two-thirds debt limitation: (1) funding or refunding a valid existing debt, (2) borrowing in anticipation of the collection of taxes due and payable within the fiscal year to an amount not exceeding 50 percent of such taxes, (3) supplying a casual deficit, (4) suppressing riots or rebellion, or repelling invasions. N.C. CoNsT. art V, $\S 4(1)$. See BYRD 259-60. The "nccessary expense" and the "two-thirds" limitations operate concomitantly to insure that virtually all long term debt to be serviced through taxes must be approved by a unit's voters.

76. Barnes Interview.

77. See notes 73-74 supra and accompanying text.

78. Primary factors for consideration are the amount of outstanding debt owed by the unit, the structure of that debt, and the unit's record for meeting debt service requirements. The Commission usually allows the question of the necessity for the debt issuance to be decided by the unit's governing board and its voters, and encounters the necessity issue only peripherally in advising a unit on ordering its priorities for capital improvement. Barnes Interview.

79. N.C. GeN. STAT. § 159-9 (1964). Before entering an order rejecting the application, the committee must notify the unit of its intention to disapprove the issue, thereby affording the unit the option of a hearing and reconsideration of the matter. Id. Presumably, if the unit did not request a hearing, the committee would enter its order of disapproval. 
its decision. ${ }^{80}$ If the committee order is negative, the unit may file for review by the full Commission within thirty days. ${ }^{81}$ Finally, an order of either the executive committee or the full Commission may be overturned by a majority of the voters of the local unit through a vote held in the same manner as an election to approve the issuance of the debt. ${ }^{82}$ However, these procedures for review are never relied upon in practice. Testing an informal decision by Commission officials through formal application to the executive committee or appealing the committee's decision to the full Commission would be unavailing, for, in reaching their decisions, both the executive committee and the full Commission tend to rely upon the disinterested expertise of the Commission's permanent staff. Moreover, resort to veto of a Commission order by a unit's voters would be financially unwise-bonds disapproved by the Commission would either not sell at all or would sell at an extremely high rate of interest. In addition, such action could jeopardize future attempts at issue by the unit.

After a unit's application for a proposed sale of bonds or notes has been approved, after the unit's residents have voted in favor of the issue (where such an election is required), ${ }^{83}$ and after certain other preliminary preparations have been made, the Commission concerns itself with its second major function-the supervision of the actual sale of the bonds or notes. ${ }^{84}$ The Commission is responsible for directing the unit's compliance with the detailed procedures of the Local Government Act which govern the mechanics of an issue from the initial notice of sale through the physical delivery of the instruments to the buyer. In order to fulfill the requirement for notice, which must be given at least ten days before the date fixed for the receipt of bids, ${ }^{85}$ the Commission prepares a bulletin announeing the sale and sends it to the unit in ample time for publication. In addition, the Commission sends both notice of the sale and a prospective sale circular to a number of potential buyers. ${ }^{86}$ The sale itself is also

80. N.C. GEN. STAT. § 159-10 (1964).

81. Id. § 159-11.

82. Id. $\S 159-10$.

83. See note 75 supra.

84. Just as all proposed debt issuance by the state's units must first be approved by the Commission, so all bonds and note of units are required to be sold by the Commission. N.C. GeN. Stat. \& 159-13.(Supp. 1971).

85. Id.

86. The sale circular contains a broad description of the issuing unit, including pertinent facts about its financial státus. Notice of sale, and sale circulars are currently mailed to approximately 280 prospective bidders. In addition, the sale is customarily advertiscd in The Daily Bond Buyer. Barnes Interview. 
carried out by the Commission through its office in the state capitol. The Commission receives sealed bids, ${ }^{87}$ opens them in public, and selects the bid which represents the lowest interest cost to the municipality. ${ }^{88}$ The Commission then formally awards the sale to the prevailing bidder and itself becomes a party to the contract for sale of the bonds or notes. ${ }^{89}$ After printing and execution, ${ }^{80}$ the bonds are delivered by the State Treasurer to the buyer ${ }^{91}$ in return for the sales price, which the Treasurer then transfers to the unit's "custodian of funds" or to its "properly designated depository."

The third major role of the Commission is its post-sale, postdelivery supervision of the issuing local unit's financial affairs to insure timely repayment of principal and interest as they become due on the bonds or notes. During this phase of the debt issuance process, the local unit must comply with several reporting requirements. The Commission may at any time require a unit, through its accountant, to submit a report on its financial condition. ${ }^{93}$ Unit officers having charge of funds are further required semi-annually, or as the Commission may direct, to report the amount of funds on hand and the security provided for them.$^{94}$ As a matter of practice, the Commission requires semi-annual statements of financial condition by a munici-

87. N.C. GEN. STAT. § 159-13 (Supp. 1971). The Commission may privately negotiate the refinancing of existing indebtedness. Id. It customarily arranges private sales of revenue bonds under the provision of $i d$. $\$ 160-421$.

88. N.C. GeN. StaT. § 159-14 (1964). No bonds are to be sold at less than par and accrued interest. If no legal bids are received, the bonds or notes may be sold at private sale. Id. $\$ 159-$ 15. Officials of the unit may reject the Commission-approved bid before it has been awarded, if they refuse all other bids. Id. § 159-16. However, due to the rapidly fluctuating market for municipal bonds and in the interest of bidders, Commission policy requires that the officials be present at the opening of the bids if they are to reject, and to make their rejection within two hours after the prevailing bid has been chosen. Rejections are rare. Barnes Interview.

89. See N.C. GEN. STAT. $§ 159-22$ (1964).

90. The Commission executes the bonds when it is satisfied that the unit has complied with all of the requirements of the Local Government Act. Id. $\$ 159-18$. Certification by the Commission is necessary to validate the bonds or notes. Id.

91. Id. $\$ 159-21$. Formal delivery is made in person by a representative of the Commission. Barnes Interview.

92. N.C. GEN. StaT. § 159-21 (1964). The statute provides for deduction of "necessary" Commission expenses from the funds received, "including the expense of advertising, selling, shipping, and delivering the bonds or notes." Id. In practice the Commission bills the unit directly for these expenditures which include charges for setting and printing bond circulars, various postage expenses, and sale-related travel expenses for Commission personnel. There is no charge for any of the Commission's supervisory services. Barnes Interview.

93. N.C. GEN. STAT. § 153-30 (1964).

94. Id. § 159-29. 
pality which list the unit's debt and the purposes for which it was incurred..$^{95}$ As the unit makes payments on its bonds and notes, it is obligated to notify the Commission of the bonds or notes paid. ${ }^{00}$ If a unit has term bonds outstanding, ${ }^{97}$ the officer having charge of sinking funds must invest them according to statutory direction ${ }^{98}$ and must make semi-annual reports to the Commission about the state of the sinking funds. ${ }^{99}$

Simultaneously, the Commission maintains a complete record of each issue of bonds or notes, keeping the information current by means of the various periodic reports of the unit. Thus, thirty days prior to the unit's annual levy of taxes, the Commission notifies the unit of the amount of tax revenues which will be required for debt retirement during the forthcoming year. ${ }^{100}$ In addition, thirty days before a payment is due to holders of bonds or notes, the Commission informs the unit of the date for performance, the amounts due, and the place for remittance. ${ }^{101}$ Where term bonds have been issued and the Commission determines that the unit's sinking funds have not been invested in eligible securities, the Commission will so notify the unit, and together with the unit will devise a plan whereby the funds will be reinvested properly. ${ }^{102}$ If sinking funds are not being maintained in sufficient amounts to retire the debt, the Commission orders the local unit to comply with the statute. ${ }^{103}$

In addition to its direct supervisory role during the debt retirement process, the Commission performs several peripheral functions and holds certain additional powers which contribute to better finan-

95. Barnes Interview. Should a problem concerning the unit's finances arise, the Commission may require additional reports. $I d$.

96. N.C. GeN. Stat. § 159-23 (1964).

97. See note 56 supra.

98. N.C. GEN. Stat. $\$ 159-25$ (Supp. 1971). The investments or deposits made are subject to the approval of the Commission's director. Id. The statute provides exclusive methods for depositing funds at interest and delineates the classes of securities in which monies may be invested. Id. $\S 159-28.1$.

99. Id. $\$ 159-27$ (1964). The reports must include the amount of the unit's sinking funds and the manner of their deposit or investment. Additional reports may be required at the discretion of the Commission. Id.

100. Id. $\$ 159-32$.

101. Id. $\$ 159-33$.

102. Id. $\$ 159-26$.

103. Id. \$ 159-24: Refusal to comply with a Commission order by a municipal offieial would seem to constitute a willful failure to perform a duty required by the Act, in violation of id. \$ 159-38 to -39 , warranting possible removal of the officer or a criminal prosecution upon complaint of the Commission's director. See notes 110-16 infra and accompanying text. 
cial management among local units and thus increase the security of the holders of bonds or notes. All contracts between local units and an accountant or auditor for audit of their books must be approved by the Commission, and the terms of the agreement must conform to standards set by the Commission. ${ }^{104}$ The Commission has the authority to require uniform systems of budget and accounting among the local units of the state. ${ }^{105}$ Moreover, the Commission is given broad remedial powers should a municipality default on its obligation to holders of bonds or notes. Where a unit has been in default for six months, the Commission has the authority to investigate the unit's finances, to advise the unit's governing board concerning refinancing or readjustment of its debt, and to negotiate with creditors. ${ }^{100}$ The unit must accept a plan that has been deemed equitable and certified by the Commission. ${ }^{107}$ Once refinancing has begun, the Commission is responsible for supervising the unit's adherence to the plan until the agreement with the creditor has been discharged. ${ }^{108}$ On the other hand, the Commission, in the event of a municipality's default, may elect to appoint an administrator of finance who will take over both the collection of taxes in the unit and the control of its funds for a period of up to one year (or longer with the governor's approval). ${ }^{109}$

As a final measure designed to establish the fiscal stability of local units and to promote the security of their creditors, the Local Government Act contains provisions designed to guard against the mismanagement of local funds which have been earmarked for the payment of principal or interest or have been designated to a unit's sinking fund. The Director of the Commission must report to the governor any failure or refusal to comply with the Act by an official of a unit or a member of the Commission, and the governor may order the offender removed from office. ${ }^{110}$ After holding a hearing and reviewing the governor's decision, the full Commission enters a final order either confirming or refusing the removal. ${ }^{111}$ If a financial officer of a unit having funds on hand fails or refuses to pay principal

104. N.C. GEN. STAT. § 153-144 (1964).

105. Id. \& 153-30.

106. See id. $\$ 159-63$ to -64 .

107. See id.

108. See id. \& 159-65 to -67 .

109. Id. § 159-31.

110. Id. \& 159-41.

111. Id. 
and interest due to holders of bonds or notes in the required amount at the designated time, he is both guilty of a misdemeanor and civilly liable for damages to the aggrieved parties." ${ }^{12}$ Similar penalties are provided for a false statement knowingly made by any person in response to a requirement of the Act; ${ }^{113}$ for the willful violation by the Director or any member of the Commission, or by any officer or member of a board of a unit, of any duty imposed upon him by the Act; ${ }^{114}$ and for misappropriation of funds raised or set aside for payment of principal, interest, or sinking funds by any member of a board of a local unit. ${ }^{115}$ Upon the complaint of the Director of the Commission, the state attorney general is to investigate any charges of a violation of the Act and may instruct the solicitor in the district in which the offense was committed to institute a criminal action against the alleged offenders. ${ }^{116}$

\section{The Commission's Success}

The Local Government Act proved to be effective as a comprehensive design to restore fiscal stability to North Carolina municipalities during the Depression. During the early years of the Commission, new debt issuance was strictly limited to give local units the opportunity to retire outstanding debt and correct default situations. ${ }^{117}$ Where new issues were allowed, Commission scrutiny of sale and retirement of these bonds brought increased efficiency and lower interest costs. At the same time, the Commission initiated refinancing plans among defaulting units. ${ }^{118}$ In many cases, after a new schedule had been set for the maturity of principal, units were able to begin paying their obligations in full. On the other hand, in cases where demanding full payment would create an excessive burden for the municipality, interest rates were reduced on the outstanding sum. ${ }^{110}$ The Commission also directed the sale and reinvestment of improperly invested securities, wisely granting municipalities sufficient

112. Id. § 159-35.

113. Id. $\S 159-37$.

114. Id. \$ 159-39.

115. Id. $\S 159-36$.

116. Id. $\S 159-40$.

117. See Ratchford, The Work of the North Carolina Local Government Commission, 25 NAT'1. MUN. Rev. 323, 324-25 (1936).

118. See generally Fesler 332-33; McMahon 108-10.

119. See McMahon 110. In only two cases was a contraction of principal allowed. Id. 
time in light of the lowered values of the Depression to make the adjustments without incurring unnecessary losses. ${ }^{120}$

The continuing success of the Commission in exercising a positive influence over local debt under the Local Government Act markedly contrasts with the experience of many states that rely solely on constitutional or statutory provisions to control local debt. North Carolina does have arbitrary constitutional and statutory restraints on municipal borrowing. The state constitution requires a majority of a unit's voters to ratify proposals to issue "nonnecessary" debt and calls for popular approval of any obligation which will be repaid beyond the current fiscal year if the amount of debt already contracted in that year or the total debt to be incurred exceeds two-thirds of the unit's net debt reduction for the preceding year. ${ }^{121}$ In addition, North Carolina statutes quantitatively limit municipal debt incurrence to ten percent of the assessed valuation of taxable property for county units ${ }^{122}$ and to eight percent of assessed value for cities and towns. ${ }^{123}$ Although similar quantitative restrictions have caused serious debt issuance problems for local governments in other states, they have had no apparent deleterious effect in North Carolina. A statutorilyrequired mandatory property revaluation program, more realistic property appraisal values, and higher assessment ratios have helped to prevent the North Carolina net debt limitation from being oppressive. ${ }^{124}$ Additionally, since the Local Government Commission's ac-

120. See Ratchford, supra note 117 , at 326.

121. See note 75 supra.

122. At present, county debt is selectively restricted. Debt for school purposes is limited to $5 \%$ of assessed valuation, except when a county has assumed all of its school districts' debt, whereupon the limit is 8\%. N.C. GeN. Stat. § 153-87 (1964). Debt for other than school purposes is limited to $5 \%$ of assessed valuation, except for bonds issued for hospital purposes. Id. $\$ \$ 131-126.23,153-87$. Effective July I, 1973, all county debt will be subject to the same restriction of $8 \%$ of appraised value by which cities and towns are to be limited. Id. § 159-55 (Supp. 1971) (eff. July 1, 1973).

123. Debt for cities and towns is currently limited to $8 \%$ of assessed valuation (bonds issued for water, gas, electric, and power facilities; sanitary sewer facilities ordered constructed by the Department of Water and Air Resources; and improvements to prevent erosion and encroachment of the ocean, are excepted from the restriction). Id. § 160-383. In 1973 the base for the debt limit becomes $8 \%$ of appraised valuation. Id. \& $159-55$ (eff. July 1, 1973). Since appraised values are significantly higher than assessed values, this change effectively raises the net debt limit. Many units assess property for taxation at $50 \%$ of appraised valuation-in such cases the statutory change will increase the limit by $100 \%$.

124. BYRD 277. The change in 1973 from assessed to appraised property values as the basis for North Carolina's net debt limitation will insure that the limit does not become unduly restrictive. See note 123 supra. 
ceptable level of debt has almost invariably been lower than the statutory maximum, ${ }^{125}$ the Commission's examination of a unit's level of existing debt and ability to support further debt prior to approval of an issue of bonds or notes has itself been a significant force for keeping municipalities' indebtedness well within the statutory limit. Moreover, due to the Commission's screening of poorlyplanned or burdensome debt and refusing to allow issuance of such debt, units themselves have been encouraged to keep debt within reasonable bounds. In the rare cases where a unit reaches the statutory debt limit and the Commission is still willing to approve further debt through the issuance of bonds or notes, the unit may obtain the legislature's approval for further borrowing. ${ }^{126}$

Because the quantitative debt limit has not proved unduly restrictive, and because Commission policy leaves units relatively free to issue debt whenever borrowing is financially feasible, ${ }^{127}$ there has been no outcry against the North Carolina net debt limit and little evidence of the costly circumvention devices commonly relied upon by municipalities in other states. ${ }^{128}$ Moreover, circumvention of the limit by persons irresponsibly managing a unit's finances would be difficult. Long-term lease or sale agreements ${ }^{129}$ are considered to create debt under North Carolina law. ${ }^{130}$ Where special districts with the power to issue bonds or notes exist, ${ }^{131}$ their issues must be approved by the Commission-the overlapping effect of this debt within another local unit is considered, and borrowing that would prove burdensome is refused. Financing through revenue bonds is not favored by the Commission because of the higher interest cost of nonguaranteed debt. ${ }^{132}$ Units are encouraged to finance revenue-producing facilities through

125. Barnes Interview.

126. See BYRD 278-79. Furthermore, although the Commission itself cannot make direct exceptions to the limit, if it is convinced of the financial feasibility of a proposed increase in net debt, it may suggest and arrange circumvention for the municipality. Barnes Interview.

127. Sce note 78 supra.

128. Sec notes 26-33 supra and accompanying text.

129. See notes 32-33 supra and accompanying text.

130. See BYRD 256. Beginning in 1973, North Carolina statutes will explicitly provide that contracts and agreements entered into by municipalities which call for payment beyond the current fiscal year are to he treated as if they were hond issues. The provision will thus expressly require that such obligations be approved by the Local Government Commission and that the sums committed thereby be counted against the legal debt limit. N.C. GeN. STAT. § 159-150 (Supp. 1971) (eff. July 1, 1973).

131. See notes 27-28 supra and accompanying text.

132. See notes 29-31 supra and accompanying text. 
general obligation bonds, making debt service payments from user charges whenever possible, but backing the bonds with the community's taxing power. ${ }^{133}$ Since the Commission will approve revenue bonds only where general obligation financing is not practicable and projections indicate with requisite certainty that a proposed facility will generate sufficient revenues to retire the debt, ${ }^{134}$ nonguaranteed debt affords no ready method for by-passing debt restriction in North Carolina.

While the Local Government Commission has been successful in exerting a flexible control over local debt incurrence, perhaps the most interesting feature of the North Carolina system has been the dollar savings to the local units (and thus indirectly to the taxpayer) which it has effected. Valuable assistance in the areas of budgeting and accounting has been given municipalities by the Commission. ${ }^{135}$ The advice, planning, and supervision during the debt issuance process represents a saving which would have been a significant expense had the unit been required to seek outside help. The greatest longrun benefits to municipalities, however, have been the savings on the interest costs of local borrowing realized through the Commission's control over the entire process of issuing bonds and notes.

A recent study has indicated that general obligation bonds of North Carolina municipalities sell at consistently lower rates of interest when compared with the other southern states as a whole. ${ }^{136}$ One of the chief reasons for the success of North Carolina bond issues has been the relatively high bond rating given the state's municipali-

133. Barnes Interview.

134. Id.

135. The Commission has aided units in establishing accounting systems and has published a reporting and auditing guide for local governments. It is presently in the process of printing and distributing a modular accounting plan designed for municipalities with populations up to 25,000 (the size units with the greatest need for such assistance). The Commission has helped units individually with other financial management problems; moreover, it has published and promoted various programs intended to increase the quality of local fiscal administration. (For example, recently it successfully initiated a program for better local cash management, emphasizing the need for investment of temporarily idle municipal funds). Barnes Interview.

136. The study showed net interest costs for North Carolina local government bonds to be 35 to 100 basis points (.35 to 1.0\%) lower than net interest incurred by other southern communities offering general obligation bonds of similar maturity with comparable debt to true property value ratios. Renshaw, Reeb \& Forbes, The States and the Local Government Bond Market, The Bond Buyer (Daily and Weekly) (MFOA Special Conference Issue, No. 2, June 21, 1971) at 61 . The saving for municipalities indicated by this interest rate differential is significant: the difference of 50 basis points $(.50 \%)$ in interest for $\$ 1$ million in bonds over twenty years represents $\$ 100,000$. 
ties. ${ }^{137}$ As the number of issues available on the national market has grown, investors have had less opportunity for detailed scrutiny of particular issues and have relied more heavily on bond ratings in choosing which unit's offering they will buy. ${ }^{38}$ Naturally, interest rates demanded by investors bidding for issues decrease as a unit's rating increases. ${ }^{139}$ In 1970, North Carolina had a larger percent of its units rated in the top three classes by one national rating agency than the other southern states. ${ }^{140}$ The state also had proportionately fewer unrated issues than either the northern, western, or southern areas. ${ }^{141}$ In addition, more North Carolina municipalities improved their ratings between 1935 and 1970 than did units in the remainder of the South..$^{142}$ The bond ratings are controlled principally by the financial condition of a unit, but the quality of information forwarded to the rating agency can influence the relative standing of a given municipality. ${ }^{143}$ By significantly contributing to the general fiscal

137. Bond ratings provide a graduated categorization of bond issues according to their estimatcd investment quality. STUDY 232. Bonds are appraised according to the risk which they entail for the potential investor. The two factors of primary importance to the bond rating agency are the risk that the issuing unit will "dilute" the bond quality through inordinate future increases in debt, thus lowering its marketability and value to the purchaser, and the risk that the unit may be unable to meet debt service requirements in the event of depressed business conditions, thereby defaulting on the bonds. Id. at 237 . To assess these two risk factors, the rating agency undertakes a detailed analysis of a community's overall financial status, its economic structure, its growth potential and cultural make-up, and its indebtedncss. See Clark, Observations Concerning the Rating of Municipal Bonds and Credits, MFOA SPECIAL BULLETIN, Oct. 1, 1971, at 4-5. See generally Clark, Local Government Bond Ratings: The Changing Scene, 34 POPULAR Gov't 20 (1968).

138. STUDY 231.

139. The difference of one grade in a rating or between similar rated and unrated issues usually results in an interest differential of 25 to 50 basis points (.25-.50\%). Id. at 236.

140. According to the study, in $1970,50.6 \%$ of North Carolina's bond issues were rated Aaa, Aa, or A by Moody's Investors Service, as compared with $28.9 \%$ for a group of eleven other southern states. D. Reeb (unpublished research, Dept. of Economics, SUNY at Albany).

141. Only 6.6\% of the North Carolina issues were unrated, contrasted to 11.4, 15.3, and $38.4 \%$ for the northern, western, and southern areas. Id. North Carolina's low number of unrated issues is significant because of the usual interest rate differential between similar rated and unrated issues. See note 139 supra. Typically, the nonrated bond is not so readily marketable as one that is rated. STuDY 240. Many investment bankers are hesitant to place unrated issues in their portfolios. As the Director of Finance for New York City noted: "When you have an unrated bond, the unrated bond unhappily has a faint odor about it, and it places a burden of proof on the individual banker to show the [bank] examiner why it is a justifiable investment." Hearings on Financing Municipal Facilities Before the Subcomm. on Economic Progress of the Joint Economic Comm., 90th Cong., 1st Sess., vol. 1, at 64 (1967).

142. $92.8 \%$ of the North Carolina unit ratings improved, while $68.7 \%$ of the ratings in other southern states advanced. D. Reeb, supra note 140.

143. See generally Clark, Observations, supra note 137, at 2-3. 
integrity of local units, by requiring units to keep accurate financial records and make periodic reports, and by encouraging and assisting units in the process of acquiring bond ratings, ${ }^{144}$ the Commission has largely determined the higher ratings of the state's municipalities.

Other factors have contributed to the lower interest costs. Investors as well as rating agencies have confidence in the state's system for controlling local debt. The Commission itself has built up good will through handling the bonds of all local units. ${ }^{145}$ Publicity and distribution of information about issues by the Commission have produced more advantageous sales. ${ }^{146}$ Perhaps the mere convenience of dealing with the Commission rather than a local unit has influenced some investors favorably. ${ }^{147}$ Certainly the expertise of the Commission gained through handling a large number of issues over an extended period of time has resulted in profitable sales within a fluctuating market.

The work of the Local Government Commission has especially benefited the small communities which issue bonds infrequently and lack the expertise to plan, prepare, and sell a bond issue. ${ }^{148}$ Small units (particularly those with populations less than 10,000) typically are penalized for their size in the rate of interest they must pay on bonds. ${ }^{149} \mathrm{~A}$ variety of factors effectuate this result: unfamiliarity with the unit by large investors, inadequacy of financial information supplied to bond analysts and investors, failure to obtain expert advice regarding bond specifications and mechanics of sale, absence of a bond rating, high overhead costs in bond marketing relative to the

144. Besides drafting and making available a publication describing bond ratings, the Commission advises units in the mechanics of obtaining ratings and periodically furnishes the rating agencies with a calendar of North Carolina issues that arc to be sold. Barnes Interview.

145. In most states when municipal bonds are sold, investors send representatives to the local unit to insure that bids are properly awarded. Sales by the Commission are usually attended only by local investors, each of whom may bring in bids from out of town or out of state firms. Barnes Interview. Being able to rely on the integrity of the Commission saves investors both money and inconvenience by eliminating the need for personal appearance at bond sales.

146. See note 86 supra.

147. In cases where a unit fails, through oversight, to make a payment of principal and interest on a bond, the bondholder cusiomarily calls the Commission to inquire about the deficiency, and the Commission, in turn, prods the local unit and gains quick compliance. The practical advantage for the investor of dealing with the central agency rather than becoming involved with a municipality is apparent. Barnes Interview.

148. For discussion of the credit problems of small municipalities, see generally STUDY 24866; Hearings, supra note 141 , vols. I \& II.

149. STUDY 248. 
small size of the issue, and lack of expertise in bond marketing. ${ }^{150}$ The Commission has helped to compensate for or to eliminate the deficiencies of smaller North Carolina municipalities in each of these areas. Although the necessity for compulsory supervision and sale of all bond issues by the Commission has on occasion been questioned, ${ }^{151}$ the control feature has been a vital factor in improving the general financial status and the debt issuing practices of small local governments. If the compulsory aspects of the statute were eliminated and supervision by the Commission were made voluntary, units planning debt issues of borderline or unacceptable feasibility would tend to avoid consultation. At present the statutory powers of the Commission underscore its recommendations to local units, thereby encouraging compliance and making actual exercise of authority largely unnecessary. ${ }^{152}$ On the other hand, the statute could probably be revised to make consultation with the Commission by large municipalities voluntary without sacrificing the efficiency of the present system. Since large units have the services of more highly qualified financial personnel and their debt issuance proposals seldom present problems for the Commission, they could be allowed to plan and sell their own bond issues.

\section{Conclusion}

The comprehensive nature of the North Carolina approach to control of local debt makes it a model suitable for adaptation to local conditions of other states. The compulsory aspects of the statute, heretofore relatively unaccepted for use elsewhere, ${ }^{153}$ might be reconsidered by other states in light of the success which has been realized in the North Carolina system without a deleterious effect on local autonomy. ${ }^{154}$ Certainly, all states and local governments which have experienced difficulties with existing systems for limiting municipal debt or are interested in lowering the cost of local borrowing (and ultimately, the taxpayer's burden), should consider some form of state supervision of local debt issuance and state technical assistance to borrowing units. North Carolina's unique Local Government Act and its pace-setting plan for local debt control by the Local Government Commission provide an established, successful, and instructive example for all such interested units.

150. Id. at 11 .

151. See Craigie, supra note 42; Stason 854-55.

152. Barnes Interview.

153. See notes 42,50 supra and accompanying text.

154. See note 77 supra and accompanying text. 